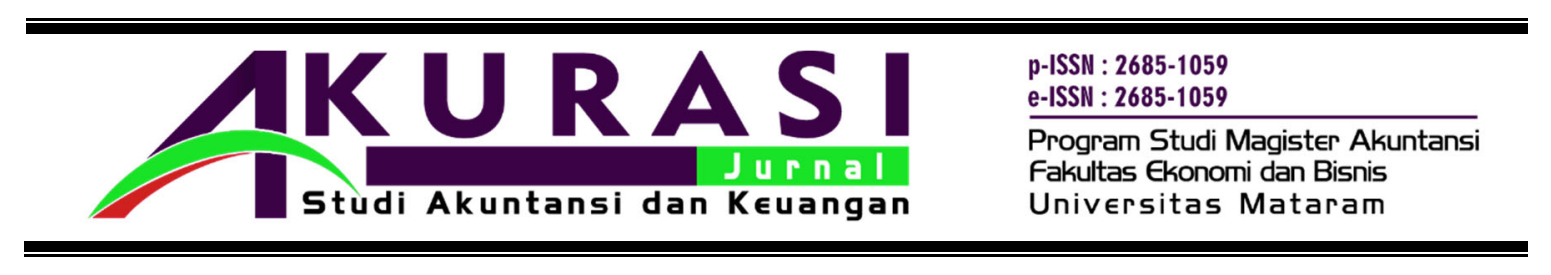

\title{
PENGARUH PILIHAN METODE MANAJEMEN LABA AKRUAL DAN RIIL TERHADAP KINERJA KEUANGAN PERUSAHAAN SEKTOR MANUFAKTUR
}

\author{
Ayu Fury Adryanti ${ }^{1}$ \\ ${ }^{1}$ Fakultas Ekonomi dan Bisnis Universitas Mataram, email : ayufurry.af@gmail.com
}

\section{INFORMASI ARTIKEL}

Article history:

Dikirim tanggal: 13/05/2019

Revisi pertama tanggal: date

Diterima tanggal: date

Tersedia online tanggal 29/06/2019

\section{ABSTRAK}

Tujuan penelitian ini adalah menguji pengaruh manajemen laba akrual dan manajemen laba riil terhadap kinerja perusahaan yang diukur menggunakan Tobin's Q. Manajemen laba akrual diproksikan dengan discretionary accrual, sedangkan arus kas kegiatan operasional perusahaan adalah proksi dari manajemen laba riil. Pengujian dilakukan pada 62 perusahaan sektor manufaktur terdaftar di Bursa Efek Indonesia periode 2015-2017. Hasil penelitian menunjukkan bahwa manajemen laba akrual dan manajemen laba riil berpengaruh signifikan positif terhadap kinerja perusahaan. Temuan ini mengindikasikan bahwa manajemen perusahaan menggunakan pemilihan metode akuntansi dan aktivitas riil perusahaan seperti penjualan, biaya produksi dan biaya diskresioner untuk mengatur pola pelaporan laba. Hasil penelitian ini mengimplikasikan investor perlu mengantisipasi terjadinya manajemen laba dengan menilai prospek perusahaan dari jumlah laba yang dilaporkan.

Kata Kunci: manajemen laba akrual, manajemen laba aktivitas riil, kinerja perusahaan, tobin's Q, akrual diskretioner

\section{ABSTRACT}

The purpose of this study is to examine the effect of accrual earnings management and real earnings management on company performance measured using Tobin's $Q$. Accrual earnings management is proxied by discretionary accruals, while cash flow of company operations is a proxy of real earnings management. Tests were conducted on 62 manufacturing sector companies listed on the Indonesia Stock Exchange in the period 2015-2017. The results showed that accrual earnings management and real earnings management had a significant positive effect on company performance. This finding indicates that company management uses the selection of accounting methods and real activities of the company such as sales, production costs and discretionary costs to regulate earnings reporting patterns. The results of this study imply that investors need to anticipate the occurrence of earnings management by assessing the prospect of the company from the amount of profit reported.

Keywords: accrual earnings management, real activity earnings management, company performance, tobin's $Q$, discretionary accruals 


\section{Pendahuluan}

Perusahaan didirikan dengan tujuan agar dapat menjaga kelangsungan hidup perusahaan dengan melakukan pertumbuhan serta meningkatkan dan mempertahankan angka laba sehingga terlihat meningkat oleh pengguna laporan keuangan serta para investor dari waktu-kewaktu. Bagi manajemen meningkatkan nilai perusahaan sangatlah penting untuk memberikan kesejahteraan kepada pemilik perusahaan. Kinerja perusahaan dalam jangka pendek dapat dievaluasi melalui laporan keuangan. Para pengguna laporan keuangan selalu menitikberatkan pada tingkat laba perusahaan karena dapat menunjukkan prestasi manajemen dalam mengelola perusahaan serta sebagai indikator dalam pengukuran kinerja manajemen. Apabila tingkat laba yang diinginkan tidak dapat tercapai maka terdapat kemungkinan adanya tindakan manajemen laba. Hal itu dibuktikan dengan adanya beberapa skandal pelaporan akuntansi yang telah diketahui, antara lain skandal manajemen yang dilakukan oleh beberapa perusahaan besar seperti Xerox Corporation yang memanipulasi pendapatan perusahaan sebesar 6M USD.

Dalam teori keagenan, masalah agensi muncul ketika satu orang atau lebih (principal) memperkerjakan orang lain (agent) untuk memberikan suatu jasa dan kemudian mendelegasikan wewenang pengambilan keputusan kepada agent tersebut. Hubungan antara principal dan agent dapat mengarah pada kondisi ketidakseimbangan informasi (asymmetrical information) karena agent berada pada posisi yang memiliki informasi yang lebih banyak tentang perusahaan dibandingkan dengan principal. Dengan asumsi bahwa individu-individu bertindak untuk memaksimalkan kepentingan diri sendiri, informasi asimetri akan memberikan peluang bagi agent untuk menyembunyikan beberapa informasi yang tidak diketahui oleh principal. Dalam kondisi informasi yang asimetri tersebut, agent dapat mempengaruhi angka-angka akuntansi yang disajikan dalam laporan keuangan dengan cara melakukan manajemen laba (earnings management).

Berbagai upaya telah dilakukan manajemen untuk meningkatkan kinerja perusahaan salah satunya yaitu dengan manajemen laba. Namun demikian, adanya praktik manajemen laba tidak dapat mencerminkan kondisi perusahaan yang sesungguhnya. Hal ini dapat menyesatkan publik, khususnya pemakai laporan keuangan karena kinerja perusahaan akan kelihatan baik namun tidak menggambarkan kondisi yang sesungguhnya. Kondisi ini berpotensi dapat menyesatkan pengambilan keputusan oleh pemakai laporan keuangan karena menggunakan informasi keuangan perusahaan yang tidak mencerminkan fakta yang sebenarnya. Beberapa pendekatan dalam manajemen laba (earning management) yaitu manajemen laba dengan pendekatan riil (real earning management) dan pendekatan akrual (accrual earning management). Model pengukuran manajemen laba akrual ini oleh beberapa peneliti dianggap masih belum dapat mengungkapkan kondisi yang lengkap tentang praktik manajemen laba karena model tersebut mengabaikan hubungan antara transaksi arus kas dan akrual. Menurut Sulistyanto (2008:212), terdapat beberapa model yang digunakan selain model Jones yaitu Model Healy. Model Healy merupakan model yang relatif sederhana karena menggunakan total akrual (total accruals) sebagai proksi manajemen laba. Selain itu ada juga model Angelo dikembangkan dengan menggunakan perubahan dalam total akrual (change in total accruals) sebagai proksi manajemen laba.

Fenomena adanya praktik manajemen laba sering terjadi dalam pengelolaan perusahaan. Sebagai contoh kasus pada PT Inovisi Infracom (INVS) pada tahun 2015 dan kasus pada PT Bank Bukopin (tbk) pada tahun 2018. Dalam kasus ini Otoritas Jasa Keuangan (OJK) menemukan indikasi salah saji dalam laporan keuangan tiga tahun terakhir, yaitu 2015, 2016, 2017 pada Toshiba Corporation. Raksasa teknologi dan elektronik asal Jepang Toshiba Corporation diindikasikan memasukkan kerugian bersih sebesar 10 miliar yen atau sekitar Rp1,17 triliun pada laporan keuangannya tahun 2014/2015. Hasil studi empiris tentang manajemen laba menunjukkan hasil yang beragam. 
Hasil penelitian Subekti dkk (2010) menunjukkan bahwa sebagian besar perusahaan publik Indonesia cenderung melakukan manajemen laba berdasarkan transaksi riil daripada transaksi akrual karena pengelolaan laba melalui aktivitas-aktivitas riil dianggap lebih dapat menggungkapkan kemampuan perusahaan dalam mengelola laba dibandingkan dengan manajemen laba berbasis akrual. Disamping itu ketertarikan manajer dalam mengelola labanya melalui aktivitas riil dikarenakan manajer memiliki kesempatan untuk memanipulasi aktivitas-aktivitas riil selama tahun buku. Studi yang berbeda dilakukan oleh Malik (2011) mengungkapkan bahwa kegiatan manajemen laba riil melekat pada perusahaan untuk mengindari adanya pelaporan rugi dan memenuhi permasalahan analisis. Melalui analisis cross sectional, penelitian ini mengungkapkan bahwa kegiatan manajemen laba riil ternyata kurang lazim terjadi pada perusahaan yang memiliki investor institusional yang besar. Sejalan dengan penelitian Subekti dkk (2010), penelitian Ningsih (2015) membuktikan bahwa manajemen laba rill sudah banyak dilakukan dan manajemen lebih menyukai dalam mengelola labanya dengan melakukan manipulasi aktivitas-aktivitas riil (manajemen laba riil).

Penelitian tentang manajemen laba melalui akrual diskresioner dan aktivitas riil dilakukan oleh Farahmita (2010) untuk menguji pengaruh manajemen laba melalui akrual diskresioner dan aktivitas riil terhadap kinerja perusahaan pada perusahaan-perusahaan yang tercatat di Bursa Efek Indonesia selama tahun 2001 sampai dengan 2007. Hasil penelitian menyimpulkan bahwa manajemen laba melalui akrual diskresioner tidak terbukti secara signifikan mempengaruhi kinerja perusahaan, sedangkan aktivitas riil terbukti secara signifikan mempengaruhi kinerja perusahaan. Berkaitan dengan manipulasi laba pada perusahaan yang melakukan Initial Public Offering (IPO), studi Anissa'rahman (2007) tidak dapat membuktikan dugaan tersebut. Namun demikian, Oktorina (2008) berhasil menemukan bukti bahwa perusahaan melakukan manipulasi aktivitas riil melalui arus kas kegiatan operasi dan mempengaruhi kinerja pada kelompok 50 perusahaan terbaik menurut Swa 100 yang memiliki total aktiva diatas Rp. 1 triliun dan EVA terbaik pada periode 2001-2006.

Fenomena manajemen laba menjadi isu yang menarik untuk diteliti. Hasil penelitian yang masih beragam dan kontradiktif mendorong peneliti untuk menguji kembali mengenai pengaruh manajemen laba melalui akrual diskresioner dan aktivitas riil terhadap kinerja keuangan perusahaan di Bursa Efek Indonesia, khususnya pada perusahaan manufaktur. Penelitian ini bertujuan menguji dua teknik manajemen laba yaitu manajemen laba akrual dan manajemen laba riil. Kedua teknik manajemen laba tersebut memiliki kelemahan dan kelebihan masing- masing sehingga mendorong manajer untuk menggunakan kedua teknik manajemen laba tersebut untuk mencapai target laba. Selain itu, penelitian ini juga bertujuan menguji dampak kedua teknik manajemen laba tersebut terhadap kinerja perusahaan. Hasil penelitian ini memberikan kontribusi bagi pemakai laporan keuangan agar lebih teliti dalam menggunakan laporan keuangan untuk pengambilan keputusan karena laporan keuangan berpotensi tidak menyajikan informasi yang sebenarnya tentang kinerja perusahaan.

\section{Kerangka Teoretis Dan Pengembangan Hipotesis Kerangka Teoretis}

Agency Theory mengargumentasikan hubungan antara principal yaitu pemilik dan agent atau manajer dalam mengelola perusahaan. Menurut Jensen dan Mecking (1976) hubungan keagenan adalah sebuah kontrak antar manajer (agent) dengan pemegang saham perusahaan (principal). Principal adalah pihak yang memperkerjakan agent agar melakukan tugas untuk kepentingan principal, sedangkan agent adalah pihak yang menjalankan kepentingan principal. Hubungan antara agent dan principal menimbulkan permasalahan agensi karena masing-masing pihak tersebut akan selalu berusaha untuk 
memaksimalkan fungsi utilitasnya tersebut. Principal menginginkan retun yang tinggi atas investasinya, sedangkan agen memiliki kepentingan untuk mendapatkan kompensasi yang besar atas hasil kerjanya. Perbedaan tujuan itulah yang menyebabkan terjadinya conflict of interest di antara pihak agen dan principal. Agent termotivasi untuk memaksimalkan pemenuhan kebutuhan ekonomi dan pisikologisnya, antara lain dalam hal memperoleh investasi, pinjaman, maupun kontrak kompensasi. Konflik kepentingan semakin meningkat terutama karena principal tidak dapat memonitor aktivitas CEO sehari-hari untuk memastikan bahwa CEO bekerja sesuai dengan keinginan dari pemegang saham. Di sisi lain, principal tidak memiliki informasi yang cukup tentang kinerja agent, sedangkan agent mempunyai lebih banyak informasi mengenai perusahaan secara keseluruhan. Hal inilah yang mengakibatkan adanya ketidak seimbangan informasi yang dimiliki oleh principal dan agent (Nasution dan Doddy, 2007).

Manajemen laba merupakan aktivitas manajerial untuk mempengaruhi dan mengintervensi laporan keuangan (Sulistyanto, 2014;51). Salah satu permasalahan yang dialami oleh manajer ialah bagaimana menentukan seberapa banyak usaha yang dilakukan untuk menjalankan perusahaan sebagai perwakilan dari pemegang saham. Orientasi pencapaian laba menimbulkan kemungkinan-kemungkinan bahwa manajer akan melalaikan kewajibannya. Laba bersih mencerminkan kinerja manajer, dan mengukur seberapa besar usaha yang telah dilakukan manajer dalam menjalankan perusahaan (Scott, 2011:26). Hal tersebut membuat manajemen berusaha untuk melakukan manajemen laba agar kinerja perusahaan tampak baik oleh pihak eksternal. Praktik manajemen laba masih dipenuhi oleh berbagai kontroversi apa lagi ini juga dikaitkan dengan perilaku etis dalam bisnis. Jauhnya sentuhan etika atas bisnis disebabkan oleh terlalu terfokusnya perhatian, tanggung jawab dan kewajiban para pelaku bisnis dan manajer untuk memperoleh keuntungan sebesar-besarnya, salah satunya dengan manajemen laba.

Penggunaan manajemen laba yang terlalu jauh dapat mengurangi kebermanfaatan laporan keuangan bagi investor. Hal ini dapat terjadi jika terdapat informasi yang tidak diungkapkan secara utuh untuk menutupi motif oportunistik manajer (Scott, 2011:423). Manajemen laba juga dapat menjadi sebuah strategi manajer untuk memperlancar kompensasi mereka. Beberapa pola manajemen laba adalah income minimization, income maximization, income smoothing dan taking bath (Scott, 2011: 425). Adapun motivasi yang mendorong manajer untuk melakukan manajemen laba dijelaskan dengan tiga hipotesis utama dalam teori akuntansi positif (Positive Accounting Theory), yaitu bonus plan hypothesis, debt covenant hypothesis dan political cost hypothesis.

Manajemen laba berbasis akrual dilakukan karena adanya keleluasaan kebijakan dari manajemen dalam menentukan suatu praktik akuntansi. Komponen akrual merupakan komponen yang digunakan dalam pencatatan dan penyusunan laporan keuangan. Praktik manajemen laba yang bersifat akrual dapat dibuktikan melalui berbagai cara salah satunya yang diukur dengan discretionary accruals dan revenue discretionary. Menurut Sulistyanto (2008) akrual merupakan selisih antara kas masuk bersih dari hasil operasi perusahaan dengan laba yang dilaporkan dalam laporan laba-rugi, yang bersifat discretionary accruals dan non discretionary accruals. Revenue discretionary merupakan pengungkapan praktik manajemen laba dengan dasar perbandingan pendapatan dan akrual untuk mengetahui berapa besar tingkat manajemen laba melalui pendapatan.

Discretionary accruals merupakan tindakan akrual yang dilakukan oleh manajer karena manajemen dapat memilih kebijakan yang akan digunakan yang terdiri dari total akrual, piutang, pendapatan dan plan, property dan equipment (PPE). Perhitungan akrual diawali dengan perhitungan total akrual. Total akrual adalah selisih antara laba dan arus kas berasal dari aktivitas operasi. Total akrual dapat dibedakan menjadi dua bagian, yaitu (1) bagian akrual yang memang sewajarnya ada dalam proses penyusunan laporan keuangan, disebut normal accruals atau non-discretionary accruals, dan (2) bagian akrual 
yang merupakan manipulasi data akuntansi yang disebut dengan abnormal atau discretionary accruals. Discretionary accruals yang merupakan akrual yang ditentukan oleh manajemen karena manajemen dapat memilih kebijakan dalam hal metode akuntasi dan estimasi akuntasi. Disinilah kelemahan dari dasar akrual yang menimbulkan peluang untuk manajer dalam melakukan praktik laba dengan tujuan tertentu.

Revenue discretionary membandingkan pendapatan tingkat kuartal ke 3 dan kuartal ke 4 serta piutang usaha yang terdapat pada laporan keuangan yang bertujuan untuk mengetahui berapa tingkat manipulasi yang digunakan dalam pengungkapan pendapatan tersebut. Stubben (2010) menyatakan bahwa pengungkapan pendapatan lebih awal (premature revenue recognition) adalah bentuk paling umum dari manajemen pendapatan. Dengan adanya pengakuan pendapatan secara premature yang dilakukan oleh perusahaan akan berdampak pada pendapatan itu sendiri dan piutang perusahaan. Dengan mengakui dan mencatat pendapatan periode yang akan datang atau belum terealisasi mengakibatkan pendapatan periode berjalan lebih besar dari pada pendapatan sesungguhnya yang berakibat seolah-oleh kinerja perusahaan lebih baik daripada kinerja sesungguhnya (Sulistyanto, 2008). Stubben (2010) mengembangkan dua formula yang berbeda yaitu revenue model dan conditional revenue model. Perubahan PSAK 1 tahun 2009 yaitu mulai efektif pada Januari 2011 menjadikan bahan pertimbangan dalam penggunaan dua formula tersebut dimana hal ini mempengaruhi penggunaan formula revenue discretionary. Formula tersebut adalah keuangan yang ada dalam prospectus yang merupakan sumber informasi yang penting yang dapat dipakai sebagai sinyal kepada calon investor mengenai informasi tentang nilai perusahaan.

Kothari et al. (2005) menjelaskan, model akrual yang biasa digunakan seperti halnya model modified Jones (Dechow et al., 1995) memiliki kelemahan, seperti halnya ketika pengujian dilakukan pada sampel yang memiliki kinerja keuangan ekstrim, begitu juga ketika dilakukan pengujian pada sampel yang tidak dipilih secara acak (Kothari et al., 2005). Kothari et al. (2005) melakukan pembentukan model yang dianggap mampu membendung permasalahan yang terjadi pada model akrual yang ada, dengan melakukan penambahan variabel return on assets (ROA) pada model pengukuran modified Jones (Dechow et al.,1995) yang dikenal dengan performance matched model.

Roychowdhury (2006) mendefinisikan tentang real earnings management (REM) atau manajemen laba riil sebagai satu bentuk manajemen laba yang dilakukan melalui manipulasi aktivitas operasional perusahaan. Manipulasi ini diukur dengan adanya satu penyimpangan dari praktik operasional perusahaan. Manipulasi ini diukur dengan adanya satu penyimpangan dari praktik operasional perusahaan yang normal. Motivasi manajemen melakukan ini adalah adanya keinginan untuk "mengelabui" pelaporan keuangan perusahaan untuk beberapa stakeholder dalam rangka memenuhi tujuan tertentu (Subekti dkk, 2010). Penyimpangan ini sebenarnya tidak memberikan nilai tambah perusahaan tetapi hanya sekedar untuk memenuhi sasaran pelaporan bagi manajer. Manajemen laba riil merupakan teknik manipulasi laba yang dilakukan oleh manajemen melalui aktivitas perusahaan sehari-hari selama periode akuntansi seperti kegiatan praktik operasional normal. Menurut Roychowdhury (2006) menyatakan bahwa campur tangan manajer dalam proses pelaporan keuangan tidak hanya melalui metode-metode atau estimasi-estimasi akuntansi saja tetapi juga dilakukan melalui keputusan-keputusan yang berhubungan dengan kegiatan operasional. Pergeseran dari manajemen akrual ke manajemen laba riil ini menurut Roychowdhury (2006) disebabkan karena :

a. manipulasi akrual kemungkinan besar akan menarik perhatian auditor atau regulatory scrutiny dibandingkan dengan keputusan-keputusan riil, seperti yang dihubungkan dengan penetapan harga dan produksi.

b. mengandalkan pada manipulasi akrual saja membawa risiko. Realisasi akhir tahun yang defisit antara laba yang tidak dimanipulasi dengan target laba yang diinginkan dapat 
melebihi jumlah yang dimungkinkan untuk memanipulasi akrual setelah akhir periode fiskal. Jika laba dilaporkan turun dari target maka kinerja perusahaan menjadi lemah sehingga praktek manipulasi melalui aktivitas riil merupakan jalan aman dalam mencapai target laba.

Graham et al. (2005) memberikan bukti pendukung bahwa para manajer lebih menyukai manajemen laba riil dibanding manajemen laba akrual, karena aktivitas manajemen laba riil sulit dibedakan dari keputusan bisnis optimal dan lebih sulit dideteksi, meskipun biaya-biaya yang digunakan dalam aktivitas tersebut secara ekonomik signifikan bagi perusahaan. Aktivitas riil seperti pengurangan biaya diskresioner lebih disukai oleh manajer dibandingkan dengan manipulasi akrual sebagai cara dalam mengatur laba. Menurut Roychowdhury (2006) manajemen laba riil dapat dideteksi melalui 3 hal yaitu arus kas operasi, biaya produksi, dan biaya diskresioner.

1. Arus kas operasi

Arus kas operasi berisi tentang rincian-rincian jumlah penerimaan dan pengeluaran kas dari kegiatan operasional perusahaan. Roychowdhury (2006) menjelaskan bahwa metode yang dilakukan agar arus kas operasi berada pada target abnormal adalah manajemen penjualan. Manajemen penjualan berkaitan dengan usaha manajer untuk meningkatkan penjualan selama periode akuntansi hal ini agar dapat meningkatkan laba yang sesuai dengan target yang telah ditetapkan. Tindakan yang dilakukan untuk meningkatkan penjualan yaitu melalui menawarkan diskon-diskon berlebih dan menawarkan persyaratan kredit yang lunak. Hal ini semua dilakukan agar volume penjualan meningkat serta mencapai target laba jangka pendek yang akan memberikan efek adanya kinerja yang baik yang ditampilkan oleh manajer. Arus kas operasi berisi tentang rincian-rincian jumlah penerimaan dan pengeluaran kas dari kegiatan operasional perusahaan selama sehari-hari. Semakin rendah nilai arus kas operasi yang abnormal maka akan semakin tinggi laba yang dilaporkan.

2. Biaya produksi

Teknik yang digunakan untuk menciptakan biaya produksi yang abnormal adalah dengan cara membesarkan volume produksi pada tahun berjalan. Peningkatan volume produksi yang tinggi ini adalah gambaran usaha untuk memotong harga atau memperpanjang toleransi masa kredit untuk meningkatkan volume penjualan atau menurunkan harga pokok produksi.

3. Biaya diskresioner

Praktik manipulasi laba melalui aktivitas riil yang selanjutnya adalah dengan cara biaya diskresioner. Biaya diskresioner adalah biaya yang outputnya tidak bisa diukur secara moneter dan tergantung pada kebijakan manajemen yang diterapkan oleh perusahaan. Selain itu biaya diskresioner yang merupakan biaya-biaya yang tidak mempunyai hubungan yang langsung dengan outputnya. Biaya diskresioner ini terdiri dari biaya iklan, biaya riset dan pengembangan, biaya penjualan, serta biaya administrasi dan umum atau yang biasa dikenal oleh perusahaan-perusahaan di Indonesia dengan sebutan biaya usaha. Perusahaan dapat mengurangi biaya diskresioner yang dilaporkan dalam beban usaha yang bertujuan untuk meningkatkan laba. Kecenderungan dilakukan ketika pengeluaran-pengeluaran tersebut tidak langsung menyebabkan pendapatan dan laba. Jika perusahaan mengurangi atau memperkecil biaya diskresioner dalam mencapai laba maka menyebabkan jumlah biaya diskresioner yang lebih rendah. Roychowdhury (2006) menyatakan apabila pengurangan biaya diskresioner dalam bentuk kas, maka pengurangan biaya-biaya tersebut akan berdampak pada arus kas keluar sehingga berdampak positif pada arus kas operasi abnormal periode tersebut dan kemungkinan menyebabkan arus kas yang rendah pada periode berikutnya. 
Husnan (1996) menyatakan bahwa kinerja perusahaan dapat dilihat dari kinerja keuangan dan kinerja saham. Kinerja perusahaan dapat diukur dengan menggunakan beberapa metode kinerja perusahaan. Sering kali kinerja perusahaan dilihat melalui perspektif keuangan yang bersumber dari laporan keuangan. Dari informasi itu, pihakpihak terkait akan melakukan perhitungan dan analisis dengan berbagai indikator pengukuran seperti profit margin ratio yang didapatkan melalui perbandingan antara net income dengan sales (total pendapatan/penjualan). Perbandingan ini menggambarkan bagaimana efektivitas perusahaan meminimalkan beban-beban operasi sehingga nilai keuntungan (net income) tidak jauh dari total penjualannya (sales).

Rasio lainnya yang juga sangat populer adalah Return on Assets atau ROA yang hampir sama dengan profit margin, hanya perbedaannya adalah dalam pengukuran ini net income dibandingkan dengan total aset perusahaan. Kedua pengukuran ini sangat populer digunakan sebagai alat ukur kinerja keuangan perusahaan, sampai beberapa pihak mulai memahami kekurangan pengukuran ini sehingga banyak pihak menyadari bahwa laporan keuangan sangat rentan dimanipulasi oleh manajemen. Untuk memperoleh angka yang besar dalam net income-nya, bisa saja perusahaan dengan sengaja mencatat penjualan yang lebih besar dari seharusnya, atau sengaja menahan pengeluaran yang seharusnya dimasukkan dalam periode tersebut. Mulai turunnya popularitas kedua rasio tersebut untuk digunakan sebagai alat ukur perusahaan memunculkan alat ukur sebenarnya yang telah lama ditemukan namun masih jarang digunakan karena memang tidak mudah diperoleh datanya dan hanya terbatas pada perusahaan yang telah terdaftar di bursa efek. Pengukuran itu dikenal dengan sebutan Tobin's $Q$ ratio. Tobin's $Q$ adalah rasio nilai pasar aset perusahaan yang diukur dengan nilai pasar dari saham yang beredar dan utang dengan biaya penggantian aset perusahaan Tobin (1969:29). Semakin tinggi nilai pasar perusahaan dibandingkan modalnya maka semakin banyak kelebihan yang dianggap sebagai laba. Tobin's $Q$ dinilai bisa memberikan informasi yang paling baik karena rasio ini mampu menjelaskan berbagai fenomena dalam kegiatan perusahaan, seperti misalnya terjadinya cross-sectional dalam pengambilan keputusan investasi serta hubungan antara kepemilikan saham manajemen dan nilai perusahaan. Tobin's $Q$ memasukkan semua unsur hutang dan modal saham perusahaan tidak hanya unsur saham biasa, sehingga rasio ini dinilai dapat memberikan informasi paling baik.

\section{Pengembangan Hipotesis}

Arus kas kegiatan operasi berisi rincian-rincian jumlah penerimaan dan pengeluaran kas dari kegiatan operasional perusahaan. Roychowdhury (2006) menjelaskan bahwa metode yang dilakukan agar arus kas operasi berada pada target abnormal adalah manajemen penjualan. Manajemen penjualan digunakan sebagai percobaan para manajer untuk meningkatkan penjualan secara temporer dalam tahun berjalan untuk meningkatkan laba dalam pencapaian target laba. Tindakan yang dilakukan dalam mempercepat metode ini adalah percepatan waktu penjualan dan atau perolehan tambahan penjualan melalui potongan harga dan kredit yang lebih ringan. Peningkatan volume penjualan karena adanya potongan harga atau diskon mungkin tidak akan terjadi ketika perusahaan kembali menetapkan harga lama. Volume penjualan yang meningkat menyebabkan laba tahun berjalan tinggi namun arus kas menurun karena kas masuk kecil akibat adanya penjualan kredit dan potongan harga, sehingga aktivitas manajemen penjualan menyebabkan arus kas kegiatan operasional periode sekarang menurun dibandingkan tingkat penjualan normal dan pertumbuhan abnormal dari piutang.

Rahman \& Hutagaol (2008) menemukan bukti saat perusahaan melakukan Initial Public Offering (IPO) menggunakan ukuran manajemen laba akrual diskresioner dan manajemen laba melalui akrual terbukti mempengaruhi kinerja pasar dalam jangka pendek. Penelitian yang dilakukan Oktorina dan Hutagaol (2008) menyatakan bahwa kinerja pasar perusahaan yang diduga cenderung melakukan manipulasi aktivitas riil melalui arus kas 
kegiatan operasi lebih tinggi dibanding dengan kinerja pasar perusahaan yang diduga cenderung tidak melakukan manipulasi aktivitas riil melalui arus kas kegiatan operasi. Hal ini dikarenakan, adanya manipulasi aktivitas riil yang dilakukan perusahaan akan membuat annual report perusahaan tampak baik, sehingga permintaan saham meningkat. Permintaan saham yang semakin tinggi menunjukkan kinerja keuangan perusahaan yang semakin tinggi. Sejalan dengan penelitian yang dilakukan oleh Oktorina dan Hutagaol (2008), penelitian yang dilakukan oleh Yusnita et al. (2015) yang menyatakan bahwa perusahaan manufaktur yang terdaftar di BEI cenderung mengeksekusi manajemen laba rill dan nyata melalui arus kas operasi dan biaya produksi. Berdasarkan argumentasi tersebut di atas dapat dirumuskan hipotesis sebagai berikut:

$\mathrm{H}_{1}$ : Manajemen laba riil berpengaruh terhadap kinerja keuangan perusahaan

Discretionary accruals yang merupakan teknik manajemen laba akrual yang kerap kali digunakan oleh manajemen dengan tindakan akrual yang dilakukan oleh manajemen karena manajer dapat memilih kebijakan yang akan digunakan. Akan tetapi kecenderuangan penggunaan manajemen laba akrual dengan discretionary accruals ini telah menjadi perhatian khusus oleh para auditor dalam pengungkapan praktik manajemen laba. Jika hal ini ini terjadi dan perusahaan terbukti menggunakan discretionary accruals maka akan memberikan pengaruh terhadap harga saham yang berkaitan langsung terhadap kinerja perusahaan tersebut. Jika manajer melakukan manajemen laba akrual tahun sekarang maka laba perusahaan akan meningkat yang akhirnya akan meningkatkan kinerja perusahaan, jika kinerja perusahaan meningkat harga pasar saham akan meningkat. Namun, pada periode berikutnya laba perusahaan akan berkurang sehingga menyebabkan kinerja perusahaan akan mengalami penurunan dalam jangka panjang dan mempengaruhi aliran kas perusahaan. Argumentasi ini sejalan dengan penelitian yang dilakukan oleh Sari dan Ahmar (2014) yang hasil penelitian membuktikan bahwa dengan menggunakan revenue model mampu mengindikasikan 8 sektor industri dari jumlah keseluruhan 13 sektor industri pada perusahaan manufaktur yang terindikasi manajmen laba akrual. Penggunaan conditional revenue model mampu menghasilkan 11 sektor industi dari jumlah keseluruhan 18 sektor industri yang terindikasi manajemen laba akrual. Yusnita et al. (2015) menemukan bahwa manajemen laba akrual yang dihitung menggunakan discretionary accruals secara parsial berpengaruh signifikan terhadap Tobin's q pada perusahaan manufaktur. Hal ini menunjukkan adanya indikasi jika perusahaan melakukan praktik manajamen laba akrual dengan discretionary accruals, maka penggunaan discretionary accruals menjadi sorotan utama auditor dalam pengungkapannya. Dengan demikian manajemen laba discretionary accruals akan berpengaruh terhadap kinerja perusahaan sehingga dapat dirumuskan hipotesis sebagai berikut:

$\mathrm{H}_{2}$ : manajemen Laba akrual berpengaruh terhadap kinerja keuangan

\section{Metode Penelitian}

Penelitian ini menggunakan studi explanatory research, yaitu penelitian yang bertujuan menjelaskan hubungan kausalitas antar variabel. Variabel dependen dalam penelitian ini adalah kinerja perusahaan, sedangkan manajemen laba akrual dan manajemen laba riil merupakan variabel independen. Populasi dari penelitian ini adalah perusahaan manufaktur terdaftar di Bursa Efek Indonesia periode 2015-2017. Sumber data peelitian adalah data sekunder berupa laporan keuangan perusahaan tahun 2015 sampai dengan 2017. Pengambilan sampel dalam penelitian ini menggunakan metode purposive sampling, yaitu pengambilan sampel dengan tujuan tertentu. Melalui teknik penyampelan tersebut, maka diperoleh jumlah sampel penelitian sebanyak 62 perusahaan manufaktur tercatat di Bursa Efek Indonesia dengan masa observasi 2015-2017. Adapun perhitungan dan kriteria pengambilan sampel dinyatakan dalam tabel 1 berikut ini: 
Tabel 1. Prosedur Penentuan Sampel

\begin{tabular}{clr}
\hline No & \multicolumn{1}{c}{ Keterangan } & \multicolumn{1}{c}{ Jumlah } \\
\hline 1 & $\begin{array}{l}\text { Perusahaan manufaktur yang terdaftar di BEI tahun } \\
2015-2017 .\end{array}$ & 149 \\
2 & $\begin{array}{l}\text { Perusahaan yang melakukan IPO, delisting, dan ganti } \\
\text { sektor di tahun 2015-2017. }\end{array}$ \\
3 & $\begin{array}{l}\text { Perusahaan yang tidak mempunyai kelengkapan data } \\
\text { yang diperlukan sesuai variabel yang diuji. }\end{array}$ & $(73)$ \\
\hline & Jumlah perusahaan sampel & $\mathbf{6 2}$ \\
\hline & Jumlah observasi (jumlah sampel x 2 tahun) & $\mathbf{1 2 4}$ \\
\hline
\end{tabular}

Pengukuran variabel dalam penelitian dijelaskan dalam definisi konseptual dan operasional sebagai berikut:

a. Kinerja keuangan. Kinerja keuangan adalah penentuan ukuran-ukuran tertentu yang dapat mengukur keberhasilan suatu perusahaan dalam menghasilkan laba. Dalam penelitian ini kinerja keuangan perusahaan diproksikan dengan menggunakan Tobin's Q sebagai ukuran penilaian pasar (Tobin, 1988). Dengan demikian rumus yang digunakan untuk menghitung Tobin's Q adalah sebagai berikut:

$$
\mathrm{Q}=(\mathrm{MVE}+\mathrm{DEBT}) / \mathrm{TA}
$$

Keterangan:

MVE : harga penutupan saham akhir tahun buku x banyaknya saham biasa yang beredar

DEBT : (utang lancar - aktiva lancar) + nilai buku persediaan + utang jangka panjang

TA : nilai buku total aktiva.

b. Manajemen laba akrual. Praktik manajemen laba akrual dilakukan dengan mempermainkan komponen-komponen akrual dalam laporan keuangan, sebab akrual merupakan komponen yang mudah untuk dipermainkan sesuai keinginan orang yang melakukan pencatatan dan penyusunan laporan keuangan (Sulistyanto, 2008). Praktik laba yang bersifat akrual atau biasa disebut manajemen laba akrual dalam penelitian ini diukur dengan model Jones yang dimodifikasi (Jones Modified Model) oleh Dechow et al. (1995) untuk menghitung discretionary accruals. Perhitungan discretionary accruals dihitung dengan cara sebagai berikut:

- Menentukan nilai total akrual dengan formulasi:

$$
\mathrm{TA}_{\mathrm{it}}=\mathrm{NI}_{\mathrm{it}}-\mathrm{CFO}_{\mathrm{it}}
$$

- Menentukan nilai parameter $\alpha 1, \alpha 2, \alpha 3$ menggunakan Jones Model (1991), dengan formulasi :

$$
\mathrm{TA}_{\mathrm{it}}=\alpha_{1}+\alpha_{2} \Delta \mathrm{ReV}_{\mathrm{it}}+\alpha_{3} \mathrm{PPE}_{\mathrm{it}}+\epsilon_{\mathrm{it}}
$$

- Melakukan skala data dengan cara semua variabel tersebut dibagi dengan asset tahun sebelumnya (Ait -1$)$, sehingga formulasinya berubah menjadi :

$$
\mathrm{TA}_{\text {it }} / \mathrm{A}_{\text {it }-1}=\alpha_{1}\left(1 / \mathrm{A}_{\mathrm{it}-1}\right)+\alpha_{2}\left(\Delta \mathrm{ReV}_{\text {it }} / \mathrm{A}_{\mathrm{it}-1}\right)+\alpha_{3}\left(\mathrm{PPE}_{\mathrm{it}} / \mathrm{A}_{\mathrm{it}-1}\right)+\epsilon_{\mathrm{it}}
$$


- Menghitung nilai NDA dengan formulasi :

$\mathrm{NDA}_{\text {it }} / \mathrm{A}_{\text {it }-1}=\alpha_{1}\left(1 / \mathrm{A}_{\mathrm{it}-1}\right)+\alpha_{2}\left(\Delta \mathrm{Rev}_{\mathrm{it}} / \mathrm{A}_{\mathrm{it}-1}-\Delta \mathrm{Rec}_{\mathrm{it}} / \mathrm{A}_{\mathrm{it}-1}\right)+\alpha_{3}\left(\mathrm{PPE}_{\mathrm{it}} / \mathrm{A}_{\mathrm{it}-1}\right)+\epsilon_{\mathrm{it}}$

- Nilai parameter $\alpha_{1}, \alpha_{2}, \alpha_{3}$ adalah hasil dari perhitungan pada langkah ke 2 Menentukan nilai akrual diskresioner yang merupakan indikator manajemen laba akrual dengan cara mengurangi total akrual dengan akrual non diskresioner, dengan formula sebagai berikut :

$$
\mathrm{DA}_{\text {it }}=\mathrm{TA}_{\text {it }}-\mathrm{NDA}_{\text {it }}
$$

$\begin{array}{ll}\text { Keterangan : } & \\ \mathrm{TA}_{\mathrm{it}} & \text { : Total akrual perusahaan i pada periode } \mathrm{t} \\ \mathrm{NI}_{\mathrm{it}} & \text { : Laba bersih perusahaan i pada periode } \mathrm{t} \\ \mathrm{CFO}_{\mathrm{it}} & \text { : Arus kas operasi perusahaan i pada periode } \mathrm{t} \\ \mathrm{NDA}_{\mathrm{it}} & \text { : Akrual non diskresioner perusahaan i pada periode } \mathrm{t} \\ \mathrm{A}_{\mathrm{it}} & \text { : Akrual diskresioner perusahaan i pada periode } \mathrm{t} \\ \mathrm{TA}_{\mathrm{it}-1} & \text { : Total asset perusahaan i pada periode } \mathrm{t}-1 \\ \Delta \mathrm{ReV}_{\mathrm{it}} & \text { : Perubahan penjualan bersih perusahaan i pada periode } \mathrm{t} \\ \Delta \mathrm{Rec}_{\mathrm{it}} & \text { : Perubahan piutang perusahaan i pada periode } \mathrm{t} \\ \mathrm{PPE}_{\mathrm{it}} & : \text { Property, Plant and Equipment perusahaan i pada periode } \mathrm{t} \\ \alpha_{1}, \alpha_{2}, \alpha_{3} & : \text { Parameter yang diperoleh dari persamaan regresi } \\ \epsilon_{\mathrm{it}} & : \text { error term perusahaan i pada periode }\end{array}$

c. Manajemen laba riil. Manajemen laba riil ini merupakan teknik manipulasi laba yang dilakukan oleh manajemen melalui aktivitas perusahaan sehari-hari selama periode akuntansi. Kegiatan manajemen laba riil dimulai dari kegiatan praktik operasional normal, hal ini yang dimotivasi oleh manajer untuk mengetahui kinerja dan kondisi perusahaan. Campur tangan manajer dalam proses pelaporan keuangan tidak hanya melalui metode-metode atau estimasi-estimasi akuntansi saja tetapi juga dilakukan melalui keputusan-keputusan yang berhubungan dengan kegian operasional (Roychowdhury (2006). Berdasarkan model Dechow et al. (1998) dan Roychowdhury (2006) menggambarkan arus kas kegiatan operasi normal sebagai fungsi linear dari penjualan dan perubahan penjualan dalam suatu periode yang di hitung sebagai berikut :

$$
\mathrm{CFO}_{\mathrm{t}} / \mathrm{A}_{\mathrm{t}-1}=\alpha_{0}+\alpha_{1}\left(1 / \mathrm{A}_{\mathrm{t}-1}\right)+\beta_{1}\left(\mathrm{~S}_{\mathrm{t}} / \mathrm{A}_{\mathrm{t}-1}\right)+\beta_{2}\left(\Delta \mathrm{S}_{\mathrm{t}} / \mathrm{A}_{\mathrm{t}-1}\right)+\varepsilon \mathrm{t}
$$

Keterangan :

$\mathrm{CFO}_{\mathrm{t}} \quad$ : Arus kas kegiatan operasi perusahaan i pada tahun $\mathrm{t}$

$\mathrm{A}_{\mathrm{t}-1} \quad$ : Total aktiva perusahaan i pada tahun $\mathrm{t}$

$\mathrm{S}_{\mathrm{t}} \quad$ : Penjualan perusahaan i pada tahun $\mathrm{t}$

$\Delta \mathrm{S}_{\mathrm{t}} \quad$ : Penjualan perusahaan i pada tahun $\mathrm{t}$ dikurangi penjualan pada tahun $\mathrm{t}-1$

$\alpha \quad:$ Koefisien regresi

$\varepsilon_{\mathrm{t}} \quad:$ error term pada tahun $\mathrm{t}$

Prosedur analisis terlebih dahulu dengan melakukan pengujian asumsi klasik yang terdiri dari uji normlaitas, heterokedastisitas, multikolinieritas dan autokorelasi. Model penelitian menguji pengaruh manajemen laba riil dan akrual terhadap kinerja perusahaan dengan asumsi manajemen melakukan kombinasi pendekatan akrual dan riil dalam melakukan manajemen laba. Adapun model persamaan matematis yang diuji adalah sebagai berikut :

$$
\mathrm{Tq}=\alpha+\beta 1 \mathrm{DA}+\beta 2 \mathrm{ABN} \_\mathrm{CFO} i+\epsilon
$$


Keterangan :

\begin{tabular}{|c|c|}
\hline $\mathrm{Tq}$ & $=$ Tobin's Q \\
\hline A & $=$ Konstanta \\
\hline B1 DA & $=$ Manajemen laba akrual \\
\hline $\begin{array}{l}\text { B2ABN_CFOi } \\
\epsilon\end{array}$ & $\begin{array}{l}=\text { Manajemen laba riil melalui arus kas operasi } \\
=\text { error }\end{array}$ \\
\hline
\end{tabular}

\section{Hasil dan Pembahasan}

\section{Statistik Deskriptif}

Analisis statistik deskriptif digunakan untuk untuk mengetahui gambaran umum data yang digunakan dalam penelitian ini sehingga dapat diketahui nilai minimum, nilai maksimum, rata-rata dan standar deviasi dari setiap variabel, baik variabel terikat maupun variabel bebas. Hasil pengujian statistik deskriptif disajikan pada tabel 1.

Tabel 1. Statistik Deskriptif

\begin{tabular}{lcrrrc}
\hline & N & Minimum & Maximum & \multicolumn{1}{c}{ Mean } & Std. Deviation \\
\hline Tobin's Q & 186 & 4,43 & 7,87 & 5,9117 &, 59208 \\
CFO & 186 & 8,86 & 15,74 & 11,8239 & 1,18475 \\
DA & 186 & 7,74 & 21,00 & 16,5359 & 2,39933 \\
Valid N & 186 & & & & \\
(listwise) & & & & & \\
\hline
\end{tabular}

Berdasarkan hasil pengujian statistik deskriptif pada tabel 1 menunjukkan bahwa rata-rata Cash Flow From Operation (CFO) menunjukkan nilai positif, sehingga perusahaan yang menjadi obyek penelitian cenderung melakukan manajemen laba riil dengan menaikkan arus kas operasionalnya. Rata-rata Discretionary Accrual (DA) menunjukkan nilai negatif, sehingga perusahaan yang menjadi obyek penelitian melakukan manajemen laba dengan cara menurunkan pelaporan laba akrualnya. Nilai Tobin's Q memiliki rata-rata 5,9117 dengan nilai minimum 4,43, dan nilai maksimum 7,87.

\section{Uji Asumsi Klasik dan Uji Regresi Linier Berganda}

Untuk memastikan bahwa syarat-syarat dalam analisis regresi terpenuhi dilakukan uji asumsi klasik. Uji asumsi klasik yang digunakan dalam penelitian ini terdiri dari uji normalitas, uji multikolinieritas, uji heteroskedastisitas dan uji autokorelasi sebagaimana disajikan pada tabel 2 berikut ini :

Tabel 2. Hasil Pengujian Asumsi Klasik

\begin{tabular}{lccc}
\hline Asymp. Sig. (2-tailed) & 0,200 & & \\
DurbinWatson & 1,909 & & \\
\hline & \multicolumn{2}{c}{ Collinearity Statistics } & Heterokedastisitas \\
\cline { 2 - 3 } \multicolumn{1}{c}{ Model } & Tolerance & VIF & Signifikansi \\
\hline Manajemen Laba Akrual & 0,970 & 1,031 & 0,952 \\
Manajemen Laba Riil & 0,970 & 1,031 & 0,707 \\
\hline
\end{tabular}

Uji normalitas digunakan untuk menguji apakah dalam model regresi variabel independen dan variabel dependen berdistribusi normal atau mendekati normal. Cara untuk mendeteksi apakah residual berdistribusi normal atau tidak yaitu dengan uji statistik KolmogorovSmirnov (K-S) adalah dimana dasar pengambilan keputusan untuk uji statistik apabila nilai signifikansi Kolmogorov-Smirnov $\geq 0,05$, maka data residual terdistribusi normal. Sebaliknya jika nilai signifikansi Kolmogorov-Smirnov $\leq 0.05$, maka data residual terdistribusi secara tidak normal (Ghozali, 2006). Dari hasil pengujian dengan menggunakan One Sample Kolmogorov-Smirnov Test pada tabel 2 dapat diketahui bahwa nilai Asymp.Sig (2-tailed) adalah 0,200 yang lebih besar dari 0,05. Hal ini menunjukkan 
bahwa berdasarkan unstandardized residual, variabel-variabel yang digunakan dalam penelitian ini, yaitu: kinerja perusahaan, manajemen laba rill dan manajemen laba akrual telah terdistribusi normal.

Multikolinieritas terjadi apabila ada satu atau lebih variabel bebas yang berkorelasi sempurna atau mendekati sempurna dengan variabel bebas lainnya, sehingga sulit sekali untuk memisahkan pengaruh/dampak dari masing-masing variabel bebas terhadap variabel terikat (Priyatno, 2008:39). Untuk mengetahui suatu model regresi bebas dari multikolinieritas antara lain adalah (1) mempunyai nilai VIF (Variance Inflation Factor) di sekitar angka 1 dan mempunyai angka Tolerance mendekati 1 . Berdasarkan tabel 2 dapat diketahui bahwa nilai tolerance variabel manajemen laba riil dan manajemen laba akrual yakni 0.970 lebih besar dari 0,10 , sedangkan nilai VIF variabel manajemen laba riil dan manajemen laba akrual yakni 1,031 lebih kecil dari 10,00. Dengan demikian dapat disimpulkan tidak terjadi masalah multikolonieritas.

Heteroskedastisitas adalah suatu keadaan dimana varian-varian dari kesalahan pengganggu tidak konstan untuk semua nilai variabel bebas. Salah satu cara untuk mengetahui heteroskedastisitas adalah dengan menggunakan uji Gletser. Hasil uji Gletser menunjukkan bahwa nilai signifikansi manajemen laba riil dan manajemen laba akrual lebih besar dari 0,05 sehingga tidak ada ketidaksamaan varian dari residual untuk semua pengamatan pada model regresi linear.

Autokorelasi adalah hubungan antara error term pada satu observasi dengan observasi lain. Diagnosis adanya autokorelasi dalam satu model regresi dilakukan melalui Uji Durbin Watson. Berdasarkan hasil pengujian autokorelasi diatas dengan menggunakan metode Durbin-Watson dapat dilihat pada tabel 2 menunjukkan nilai Durbin-Watson sebesar 1.909, yang berada diatas nilai du sebesar 1,7163 dan lebih rendah dari 4-du. Dengan demikian diperoleh hasil 1,7163 $<1.909<2,2837$, dimana nilai Durbin-Watson sebesar 1.909 berada diantara du dan 4-du sehingga dapat dinyatakan bahwa model regresi ini tidak terdapat masalah autokorelasi.

Hasil pengujian regresi liner berganda yang menunjukkan hasil uji $\mathrm{F}$, nilai koefisien determinasi dan hasil pengujian signifikansi parameter individual dinyatakan pada tabel 3 berikut ini:

Tabel 3. Ringkasan Hasil Pengujian Regresi Linier Berganda

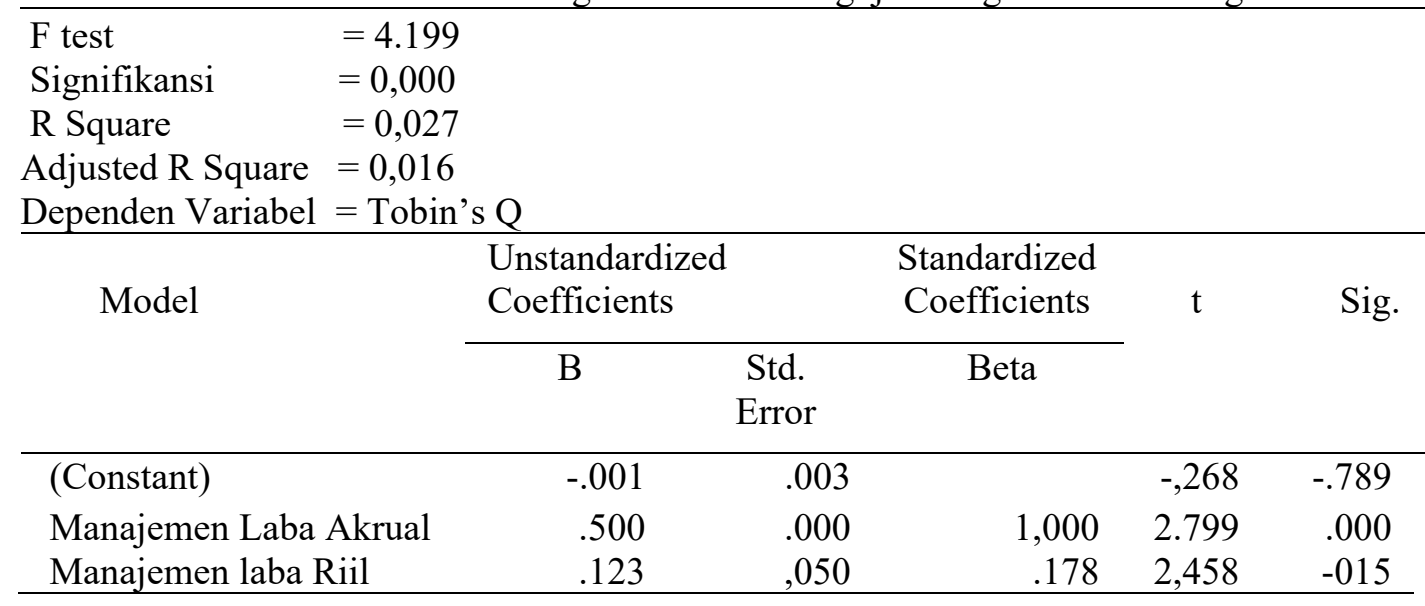

Berdasarkan tabel 3 dapat diketahui bahwa hasil uji ketepatan model atau Uji $\mathrm{F}$ menunjukkan nilai signifikan dibawah 0,05 dan nilai statistik F sebesar 4,199 lebih besar dari 1,96 sehingga dapat dinyatakan model layak digunakan untuk prediksi. Uji koefisien determinasi $\left(\mathrm{R}^{2}\right)$ bertujuan untuk menguji sejauh mana tingkat keterikatan atau kontribusi variabel manajemen laba akrual (DAC) dan manajemen laba riil (CFO) terhadap variabel kinerja perusahaan (Tobin's Q) yang dapat dilihat dari besarnya nilai koefisien determinasi (adjusted R-square). Berdasarkan tabel 3 dapat diketahui nilai $R$ Squre sebesar 
0,027 atau $2.7 \%$ (nilai 0.027 adalah pengkuadratan dari koefisien korelasi atau $\mathrm{R}$, yaitu $0.164 \mathrm{x} 0.164$ ) yang menunjukkan kontribusi dari variabel bebas yang terdiri dari discretionary accrual (DA) dan arus kas operasi (CFO) terhadap kinerja perusahaan (Tobin's Q). Sedangkan sisanya $(100 \%-2.7 \%=97.3 \%)$ dikontribusikan oleh faktor lainnya di luar model yang dispesifikasikan. Koefisien korelasi berganda ditunjukkan dengan (R) sebesar 0,164 atau 16.4\% yang menunjukkan hubungan antara variabel bebas tersebut terhadap kinerja perusahaan (Tobin's Q).

Hasil pengujian signifikansi parameter individual atau uji t menunjukkan bahwa manajemen laba akrual berpengaruh positif terhadap kinerja perusahaan yang diukur dengan tobin's Q. Hal ini ditunjukkan oleh nilai signifikansi sebesar 0,000 lebih kecil dari 0,05 dengan arah hubungan koefisien positif. Dengan demikian hipotesis pertama dalam penelitian ini yang menyatakan bahwa manajemen laba akrual berpengaruh terhadap kinerja perusahaan didukung. Dalam penelitian ini discretionary accruals sebagai proksi dari manajemen laba akrual berpengaruh terhadap kinerja perusahaan juga memiliki arah positif. Hal ini dikarenakan pengungkapan discretionary accruals menjadi perhatian para auditor untuk pendeteksiannya dan jika perusahaan terdekteksi melakukan manajemen laba akrual maka akan berdampak terhadap harga pasar yang mempengaruhi suatu nilai perusahaan. Discretionary accruals merupakan akrual yang ditentukan manajemen karena manajemen dapat memilih kebijakan dalam hal metode dan estimasi akuntansi. Disinilah kelemahan dari dasar akrual yang menimbulkan peluang untuk manajer mengimplementasikan strategi manajemen laba. Dengan diterapkannya manajemen laba akrual dengan discretionary accruals diharapkan dapat memberikan pengaruh terhadap laba yang dilaporkan. Hal ini terjadi karena manajemen dapat memilih kebijakan dalam hal metode dan estimasi akuntansi dengan memperhitungkan property, pabrik dan peralatan dan perubahan pendapatan yang disesuaikan dengan perubahan piutang yang akan mempengaruhi laba yang diperoleh pada akhir periode dengan laba yang tinggi inilah mampu mensejahterakan para pemilik serta meningkatkan suatu nilai perusahaan.

Hasil penelitian ini mendukung penelitian yang dilakukan Yusnita et al. (2014) yang menyatakan bahwa discretionary accrual berpengaruh positif signifikan terhadap kinerja perusahaan yang menggunakan proksi tobins'Q. Namun demikian hasil penelitian tidak sejalan hasil penelitian yang dilakukan oleh Herawaty (2008) yang menyatakan bahwa manajemen laba akrual yang dihitung menggunkan discretionary accruals berpengaruh signifikan terhadap nilai perusahaan. Hasil penelitian ini juga tidak konsisten dengan hasil penelitian yang dilakukan oleh Farahmita (2010), Ahmar dan Wahyu (2014) yang menemukan bahwa discretionary accruals berpengaruh negatif terhadap nilai perusahaan.

Hasil uji signifikansi parameter individual (uji t) terhadap pengaruh manajemen laba riil terhadap kinerja perusahaan (Tobin's Q) menunjukkan nilai signifikansi 0.015 yang lebih kecil dari 0,05 dengan arah koefisien positif. Hasil ini menunjukkan bahwa hipotesis kedua dalam penelitian ini yang menyatakan bahwa manajemen laba riil berpengaruh terhadap kinerja perusahaan didukung. Manajemen laba riil merupakan penyimpangan dari aktivitas operasi normal perusahaan yang merujuk pada permainan angka laba yang dilakukan melalui aktivitas-aktivitas yang berasal dari kegiatan bisnis normal atau yang berhubungan dengan kegiatan operasional. Hasil analisis uji $t$ menunjukkan nilai signifikansi yaitu $0,000<0,05$ dapat disimpulkan bahwa variabel manajemen laba riil dengan pendekatan arus kas operasi berpengaruh terhadap variabel kinerja perusahaan dengan indikator Tobin's Q.

Hasil pengujian ini konsisten dengan hasil penelitian yang dilakukan Ferdawati (2012), Hermanto dan Sa'diyah (2017) serta Oktorina (2008) dan Farahmita (2010) yang menunjukkan bahwa manajemen laba riil terbukti berpengaruh positif terhadap kinerja perusahaan (Tobin's Q). Secara umum investor di Indonesia lebih banyak melihat nilai 
laba dari pada nilai Q yang dijadikan sebagai pedoman untuk mengambil keputusan investasi. Hal ini karena nilai laba dapat terlihat secara langsung pada laporan keuangan, sedangkan nilai Q tidak terdapat pada laporan keuangan melainkan harus menghitung terlebih dahulu. Hal ini mengindikasikan bahwa variabel kinerja perusahaan (Tobin's Q) ternyata dipertimbangkan dalam melakukan penilaian perusahaan. Hasil penelitian ini konsisten dengan penelitian terdahulu seperti Challen dan Siregar (2012) serta Rahman dan Hutagaol (2008) bahwa aktivitas real earnings management mempunyai pengaruh positif terhadap kinerja perusahaan dalam konteks perusahaan di Indonesia.

Penelitian ini dapat menjadi informasi bagi para pelaku bisnis khususnya di Indonesia mengenai manajemen laba. Setiap perusahaan dalam mengatur pola pelaporan laba dapat dilakukan melalui pemilihan terhadap metode manajemen laba. Untuk mengatur laba yang ingin dilaporkan, manajer tidak hanya melakukan manajemen laba melalui pemilihan metode akuntansi saja, tapi juga melalui manipulasi aktivitas riil perusahaan. Manipulasi aktivitas riil dapat dilakukan melalui tiga cara, yaitu manipulasi penjualan, manipulasi biaya diskresioner dan manipulasi biaya produksi. Apabila perusahaan melakukan potongan harga yang cenderung tinggi dalam jumlah besar atau memberikan kredit dengan syarat lunak, maka perusahaan tersebut terindikasi melakukan kegiatan mengatur laba melalui manipulasi penjualan dengan tujuan untuk melaporkan laba jangka pendek yang tinggi. Jika perusahaan melakukan pengurangan yang cukup drastis dalam alokasi biaya pengembangan dan biaya iklan, kemungkinan menandakan bahwa perusahaan sedang berupaya untuk mengurangi beban pada periode tersebut agar menunjukkan laba yang tinggi. Begitu juga apabila perusahaan melakukan produksi secara besar-besaran jauh diatas level normal perusahaan, mengindikasikan bahwa perusahaan tersebut berupaya menurunkan haga pokok produksi, dan meningkatkan jumlah produk yang dijual sehingga dapat melaporkan laba yang tinggi. Oleh karena itu, investor perlu menganalisis adanya manajemen laba disetiap perusahaan manufaktur yang terdapat perbedaan dalam pemilihan antara manajemen laba rill dan manajemen laba akrual. Investor juga perlu menganalisis kemungkinan terjadinya manajemen laba, agar pelaku bisnis tidak mengambil analisis yang salah karena hanya menilai prospek perusahaan dari jumlah laba yang dilaporkan.

\section{Kesimpulan, Implikasi dan Keterbatasan}

Tujuan penelitian ini adalah menguji pengaruh manajemen laba akrual dan manajemen laba riil terhadap kinerja perusahaan yang diukur dengan menggunakan Tobin's Q. Dalam hal ini Discretionary Accrual (DA) merupakan proksi dari manajemen laba akrual, sedangkan arus kas operasional merupakan proksi dari manajemen laba riil. Pengujian dilakukan pada 62 perusahaan manufaktur yang terdaftar di BEI sejak tahun 2015-2017. Hasil pengujian dengan regresi linier berganda menunjukkan bahwa manajemen laba akrual dan manajemen laba riil berpengaruh positif terhadap kinerja perusahaan. Semakin tinggi aktivitas manajemen laba riil akan semakin meningkatkan kinerja perusahaan. Di sisi lain, kinerja perusahaan juga meningkat ketika perusahaan mampu mengatur pelaporan laba melalui pemilihan metode akuntansi dengan menggunakan manajemen laba akrual.

Hasil penelitian ini mengindikasikan bahwa setiap perusahaan dalam mengatur pola pelaporan laba dapat dilakukan melalui pemilihan terhadap metode manajemen laba, baik yang dilakukan dengan manajemen laba akrual melalui pemilihan metode akuntansi saja atau melalui aktivitas riil perusahaan. Perusahaan juga dapat menggunakan metode tersebut secara bersamaan dalam pelaporan laba perusahaan. Motivasi manajer melakukan manipulasi aktivitas akrual melalui discretionary accrual adalah untuk menghindari kerugian atau mencapai target laba tertentu pada periode bersangkutan dan apabila laba tinggi maka harga saham atau kinerja keuangan perusahaan akan cenderung meningkat. 
Setiap perusahaan dalam mengatur pola pelaporan laba dapat dilakukan melalui pemilihan terhadap metode manajemen laba. Untuk mengatur laba yang ingin dilaporkan, manajer tidak hanya melakukan manajemen laba melalui pemilihan metode akuntansi saja, tapi juga melalui manipulasi aktivitas riil perusahaan. Manipulasi aktivitas riil dapat dilakukan melalui tiga cara, yaitu manipulasi penjualan, manipulasi biaya diskresioner dan manipulasi biaya produksi. Oleh karena itu, investor perlu menganalisis kemungkinan adanya manajemen laba di setiap perusahaan manufaktur baik yang dilakukan melalui aktivitas riil atau akrual sehingga investor dapat mengambil keputusan bisnis dan investasi yang tepat terhadap prospek perusahaan dari jumlah laba yang dilaporkan.

Keterbatasan dalam jumlah observasi membuka peluang penelitian selanjutnya dengan untuk menambah tahun pengamatan dan sampel yang lebih representatif terhadap populasi. Selain itu untuk penelitian manajemen laba diharapkan model penelitian dapat menginternalisasi variabel kontrol seperti ukuran perusahaan, tingkat profitabilitas dan karakteristik perusahaan lainnya. Disarankan juga untuk penelitian selanjutnya agar menggunakan sampel perusahaan bukan manufaktur saja tetapi semua jenis perusahaan sektor yang lainnya karena setiap sektor memiliki karakteristik akrual yang berbeda.

\section{Referensi}

Ahmar, N dan Wahyu S, 2014. Pengaruh Manajemen Laba Akrual dengan Pendekatan Revenue Discretionary Model terhadap Kinerja Perusahaan, Trikonomika, 13 (1), $108-118$.

Annisaa'rahman, dan Yanthi H. 2007.Earnings Management melalui Accruals dan Real Activities Manipulation pada Initial Publik Offerings dan Kinerja Jangka Panjang (Studi Empiris pada Bursa Efek Jakarta). the $1^{\text {st }}$ Accounting Conference, Fakultas Ekonomi - Universita Indonesia.

Challen, E.A dan Siregar, V.S. 2012. Audit Qyality on Earnings Management and firm value. Finance and Banking Journal, 14 (1).

Dechow, Sloan, dan Sweeney. 1995. Detecting Earnings Management. The Accounting Review, 70 (2), 193-225.

Priyatno, Dewi. 2008. Mandiri belajar SPSS-bagi mahasiswa dan Umum, Yogyakarta: Media Kom.

Farahmita. 2010. Pengaruh profitabilitas, Nilai perusahaan, dan struktur kepemilikan terhadap praktik pralatan laba: Studi empiris perusahaan manufaktur yang terdaftar di BEI. SNA XIII. Purwokerto.

Ferdawati. 2009. Pengaruh Manajemen Laba Real terhadap Nilai Perusahaan. Jurnal Akuntansi \&Manajemen, 4 (1): 59-74.

Ghozali, Imam, 2006. Aplikasi Analisis Multivariate dengan Program SPSS, Edisi Ke-4. Semarang: Badan Penerbit Universitas Diponegoro.

Graham, Jhon R.; Campbell R. Harvey; dan S. Rajgopal. 2005. The Economic Implications of Corporate Financial Reporting. Journal of Accounting \& Economics, 40, 3-73.

Herawaty, V. 2008. Peran Praktek Corporate Governance sebagai Moderating Variable dari Pengaruh Earnings Manajemen terhadap Nilai Perusahaan. Simposium Nasional Akuntansi XI Yogyakarta: 23-24.

Husnan, Suad, 1996. Manajemen keuangan teori penerapan (Keputusan Jangka Panjang), edisi 4 , Yogyakarta : BPFE

Ikatan Akuntan Indonesia. 2015. Standar Akuntansi Keuangan. Jakarta: Salemba Empat.

Jensen, Michael C., dan William H. Meckling, 1976. Theory of The Firm: Managerial Behavior, Agency and Ownership Structure. Journal of Financial Economic,3 (4), 305-360.

Kothari, S.P., Leone, A.J., \& Wasley, C.E.2005. Performance Matched Discretionary Accrual Measures. Journal of Accounting and Economics, 39 (1), 163-197. 
Malik, Hifza 2011. Determinants Of Insurance Companies Profitability: An Analysis Of Insurance Sector Of Pakistan. Academic Research International, 1(3), 315-321.

Nasution, Mariot dan Doddy Setiawan, 2007. Pengaruh Corporate Governance Terhadap Manajemen Laba di Industri Perbankan Indonesia. SNA X Makasar.

Ningsih, S. 2015. Pengelolaan Laba Melalui aktivitas-aktivitas riil perusahaan perspektif islam. Universitas Muhammadiyah Surakarta.

Oktorina, Megawati, dan Yanthi H. 2008. Analisis Arus Kas Kegiatan Operasi dalam Mendeteksi Manipulasi Aktivitas Riil dan Dampaknya Terhadap Kinerja Pasar.Simposium Nasional Akuntansi (SNA) XI. Pontianak.

Rahman, Annisaa' dan Yanthi Hutagaol. 2008. Manajemen Laba Melalui Akrual dan Aktivitas real pada Penawaran Perdana dan Hubungannya dengan kinerja jangka panjang. Jurnal Akuntansi dan Keuangan Indonesia, 5 (1), 1-29

Roychowdhury, S. 2006. Earnings Management through Real Activities Manipulation. Journal of Accounting and Economics, 42, 335-370.

Sari, N. H. dan N. Ahmar 2014. Revenue Discretionary Model Pengukuran Manajemen Laba: Berdasarkan Sektor Industri Manufaktur di Bursa Efek Indonesia. Jurnal Akuntansi dan Keuangan, 16(1) :43-51.

Scott, William R. 2011. Financial Accounting Theory (Sixth Edition). USA: Pearson Canada Inc.

Sa'diyah, Siti dan Hermanto, S.Bambang. 2017.Pengaruh manajemen laba akrual dan manajemen laba rill terhadap nilai perusahaan. Jurnal Ilmu dan Riset Akuntansi, 6 (9).

Stubben, S.R., 2010. Discretionary Revenues as a Measure of Earnings Management. The Accounting Review, 85 (2), 695-717.

Subekti. I, Kee PL, dan Ahmad Z. (2010). The Effect of Integrated Earnings Management on The Value Relevance of Earnings and Book Value of Equity. Simposium Nasional Akuntansi (SNA) : 13. Purrwokerto.

Sulistyanto, H. Sri. 2014. Manajemen Laba.Teori dan Metode Empiris. Jakarta: Grasindo.

Tobin, J. 1969. A General Equilibrium Approach to monetary Theory. Journal of Money, Credit and Banking 1 (1), 15-29.

Tobin, J. 1988. Tobin's Q Ratio as An Indicator of The Valuation Of The Company. Journal of Financial Economics III (3), 287-298.

Yusnita, H., Mulyadi, dan Erick. 2015. Pengaruh Manajemen Laba Akrual dan Manajemen Laba Riil Terhadap Kinerja Perusahaan. JAFFA 3(1): 1-6. 